\title{
Poglądy i oczekiwania kobiet wobec badań ginekologicznych
}

\section{Views and expectations of women regarding gynaecological examinations}

\author{
Katarzyna Szymoniak ${ }^{1}$, Witold Malinowski², Dorota Ćwiek ${ }^{1}$, Dorota Fryc ${ }^{1}$, Małgorzata Zimny ${ }^{1}$ \\ 1 Pomorski Uniwersytet Medyczny w Szczecinie, Samodzielna Pracownia Umiejętności Położniczych, ul. Żołnierska 48, 71-210 Szczecin \\ 2 Pomorski Uniwersytet Medyczny w Szczecinie, Katedra i Zakład Pielęgniarstwa Położniczo-Ginekologicznego, ul. Żołnierska 48, 71-210 Szczecin \\ $\triangle$ ka_szym@wp.pl
}

\begin{abstract}
Introduction: It has long been known that gynaecological examination causes a lot of negative emotions for most women.

The aim of the study was to learn the views of women on the issue of gynaecological examination.

Materials and methods: The study involved 1200 women from the West Pomeranian and Łódź provinces in Poland.

Results: The majority of non-pregnant women considered gynaecological examination to be embarrassing. The most embarrassing moment of the visit for the respondents from both groups was lying down on the gynaecological chair, and the most unpleasant stage of examination was palpation through the vagina. The greatest sense of security and mental comfort during the examination was provided by the presence of only the gynaecologist. Most pregnant respondents prefer to be examined by a male gynaecologist. Respondents would most willingly have examinations with a doctor who is nice, talkative, calm, smiling and
\end{abstract}

mature. Most of the pregnant surveyed women claimed that the gynaecological examination is very necessary, while only $49 \%$ would appear for it once every 6 months.

Conclusions: 1. Gynaecological examination was significantly more embarrassing and stressful for women who were not pregnant. 2. In the opinion of pregnant women, breast examination is the least embarrassing stage of the examination. 3. Pregnant women significantly more often chose a man as their gynaecologist. 4. The frequency of having a gynaecological examination depended significantly on the status of pregnancy. 5. The expectations of the surveyed women to a gynaecologist focused mainly on him/her maintaining a sense of intimacy and security, on informing the women on the procedures taken, as well as on a nice and individual approach.

Keywords: women's opinions; gynaecologist; gynaecological surgery.

\begin{abstract}
ABSTRAKT
Wstęp: Wiadomo od dawna, że badanie ginekologiczne budzi u większości kobiet wiele negatywnych emocji.

Celem pracy było poznanie poglądów kobiet na temat istoty badania ginekologicznego.

Materiały i metody: Badaniami objęto 1200 kobiet z województwa zachodniopomorskiego i łódzkiego.

Wyniki: Większość kobiet nieciężarnych uznała badanie ginekologiczne za krępujące. Za najbardziej krępujący momenty wizyty respondentki z obu grup uważały położenie się na fotelu ginekologicznym, a za najbardziej nieprzyjemny etap badania ręczne badanie przez pochwę. Największe poczucie bezpieczeństwa i komfortu psychicznego w trakcie badania kobietom ciężarnym zapewniała obecność wyłącznie lekarza ginekologa. Większość respondentek ciężarnych woli być badana przez lekarza mężczyznę. Respondentki najchętniej odbywałyby badanie u lekarza
\end{abstract}

miłego, spokojnego, w dojrzałym wieku. Większość ankietowanych ciężarnych twierdziła, że badanie ginekologiczne jest bardzo potrzebne, przy czym zaledwie $49 \%$ zgłaszałoby się na to badanie raz na 6 miesięcy.

Wnioski: 1. Badanie ginekologiczne było istotnie bardziej krępujące i stresujące dla kobiet niebędących w ciąży. 2. W opinii kobiet ciężarnych badanie piersi jest najmniej krępującym etapem badania. 3. Kobiety ciężarne istotnie częściej wybierały na swojego lekarza ginekologa mężczyznę. 4. Częstotliwość zgłaszania się na badania ginekologiczne istotnie zależała od stanu brzemiennego kobiety. 5. Oczekiwania badanych kobiet wobec lekarza ginekologa skupiały się głównie na zapewnieniu przez niego poczucia intymności, bezpieczeństwa, informowania o procedurach, a także miłego i indywidualnego podejścia.

Słowa kluczowe: opinie kobiet; lekarz ginekolog; gabinet ginekologiczny.

\section{WSTĘP}

Wiadomo od dawna, że badanie ginekologiczne budzi u większości kobiet wiele negatywnych emocji. Dotyczy ono bowiem tych sfer i problemów życia, które powszechnie traktowane są jako najbardziej intymne. Pacjentka przychodząc do lekarza ginekologa, wstępuje do gabinetu lekarskiego z balastem wstydliwości, skrępowania oraz strachu od lat kształtowanym przez sposób wychowania w domu rodzinnym, a dodatkowo uwarunkowanym kulturowo, religijnie i zwyczajowo przez wpływ otaczającego ją społeczeństwa. W ostatnich latach obserwuje się znaczne zmiany w polskiej ginekologii. Zmiany te dotyczą zarówno rozwoju technik diagnostycznych oraz leczniczych, jak i wymagań stawianych przez pacjentki wobec 
lekarzy ginekologów. Kobiety oczekują od lekarzy umiejętności właściwego komunikowania się, czyli relacji opartej na wzajemnym szacunku i zrozumieniu. Oczekują również odpowiednio wyposażonych gabinetów ginekologicznych. Coraz więcej pacjentek chce świadomie i aktywnie uczestniczyć w poznaniu i akceptacji decyzji dotyczących ich zdrowia oraz mieć wpływ na wybór procesu leczenia. Współczesne kobiety oczekują, że gabinety lekarskie, do których przyjdą, będą urządzone w sposób dla nich przyjazny, stwarzający miłą, ciepłą, wręcz domową atmosferę.

W niniejszej pracy dokonano podziału kobiet na ciężarne i nieciężarne, co pozwoliło na ustalenie, do jakiej grupy pacjentek trzeba podejść ze szczególnym zaangażowaniem, aby przemóc ich wstyd, pokonać obawy, a także w jaki sposób należy to uczynić. Dzięki tym działaniom kobiety z pewnością będą zgłaszały się do lekarza ginekologa częściej i bardziej regularnie, co z pewnością zwiększy wykrywalność i da możliwość wyleczenia schorzeń narządów płciowych.

Celem badań było poznanie poglądów kobiet na temat istoty badania ginekologicznego oraz ich oczekiwań wobec lekarza ginekologa.

\section{MATERIAŁY I METODY}

Anonimowymi badaniami objęto 1200 losowo wybranych kobiet z województwa zachodniopomorskiego i łódzkiego. Respondentki podzielono na dwie grupy badawcze. Grupę I (400 osób) stanowiły kobiety ciężarne, natomiast grupę II (800 osób) pacjentki niebędące w ciąży. Badania przeprowadzono w prywatnych gabinetach ginekologicznych (300 osób) oraz szpitalnych oddziałach ginekologicznych (500 osób), oddziałach patologii ciąży (300 osób) i oddziałach położniczych (100 osób).

Respondentki podzielono na dwie grupy ze względu na miejsce zamieszkania. Wiek kobiet wahał się w granicach między 19. a 61. r.ż. Badania przeprowadzono metodą sondażu diagnostycznego, za pomocą ankiety własnego autorstwa, która zawierała metryczkę do pozyskiwania danych o pacjentkach oraz 14 pytań właściwych. Analizę statystyczną pozyskanych danych przeprowadzono za pomocą programu Statistica 7.1 PL oraz testu $\chi^{2}$ Pearsona i NW, testu dla dwóch wskaźników struktury, a także testu Fishera-Snedecora.

\section{WYNIKI}

Spośród 1200 ankietowanych największą grupę 723 (60,3\%) osób stanowiły kobiety pochodzące z miast. Mieszkanek wsi było 477 (39,7\%).

Większość respondentek (733 osób - 56,8\%) uważała, że badanie ginekologiczne jest krępujące i stresujące. Dokonując analizy respondentek ze względu na grupy, wykazano, że istotnie częściej badanie ginekologiczne krępowało kobiety niebędące w ciąży (506 osób - 63,2\%). Istotność statystyczna ukształtowała się na poziomie $\mathrm{p}<0,05$.
Zarówno badane z grupy I, jak i grupy II za najbardziej krępujący moment wizyty u lekarza uważają położenie się na fotelu ginekologicznym (I - 146 osób, 36,5\%; II - 260 osób, 32,5\%), badanie ginekologiczne (I - 128 osób, 32\%; II - 243 osób, $30,4 \%$ ) oraz przygotowanie się do badania, czyli rozebranie się (I - 99 osób, 24,8\%; II - 2010sób, 25,1\%) - rycina 1. Nie wykazano różnic istotnych statystycznie.

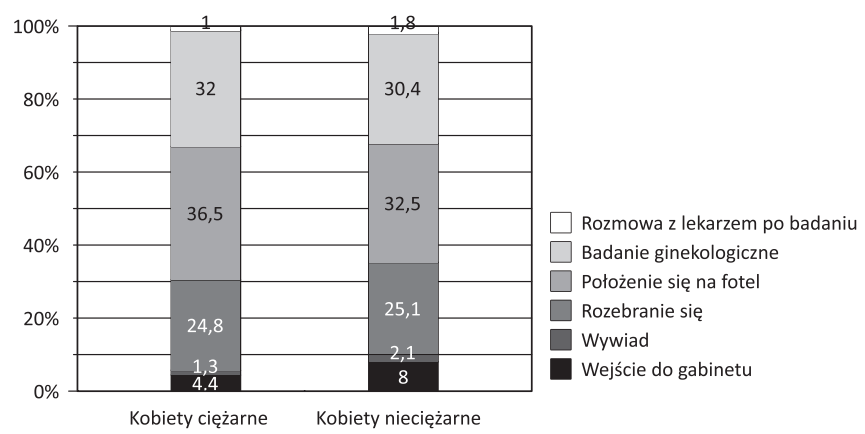

RYCINA 1. Najbardziej krępujące sytuacje podczas wizyty u ginekologa

Analiza dotycząca poszczególnych etapów badania ginekologicznego wykazała różnice istotne statystycznie $(\mathrm{p}<0,05)$. Dla kobiet zarówno ciężarnych, jak i niebędących w ciąży bardziej krępujące było ręczne badanie przez pochwę (I - 148 osób, 37\%; II - 306 osób, 38,3\%), badanie przez odbytnicę (I - 134 osób, 33,5\%; II - 265 osób, 33,1\%) oraz wziernikowanie pochwy (I - 113 osób, 28,3\%; II - 192 osób, 24\%). Natomiast badanie piersi istotnie częściej krępowało respondentki nieciężarne (37 kobiet - 4,6\%) - rycina 2 .

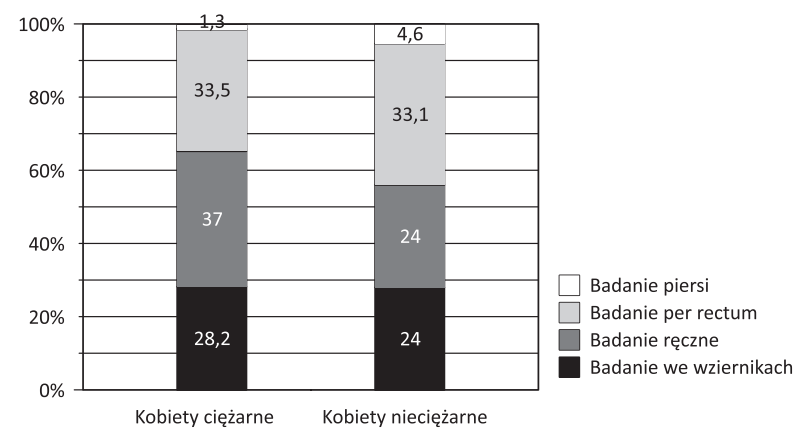

RYCINA 2. Najbardziej krępujące etapy badania ginekologicznego

Następnie ankietowane zapytano o potrzebę i częstość wykonywania badań ginekologicznych. Wykazano, iż większość kobiet ciężarnych (98,5\%) istotnie częściej twierdziła, że badanie ginekologiczne jest bardzo potrzebne $(p=0,00)$. Analiza podziału kobiet na grupy wykazała, iż respondentki ciężarne istotnie częściej zgłaszałyby się na badanie raz na 6 miesięcy (196 osób - 49,0\%), w przeciwieństwie do kobiet niebędących w ciąży, które istotnie częściej przychodziłyby na badanie kontrolne do ginekologa raz na 12 miesięcy (264 osób - 33,0\%) p < 0,05. Niepokojący jest fakt, że aż 69 (17,2\%) ciężarnych i $163(20,4 \%)$ kobiet nieciężarnych zgłaszałoby się na badanie rzadziej niż raz na dwa lata (ryc. 3). 


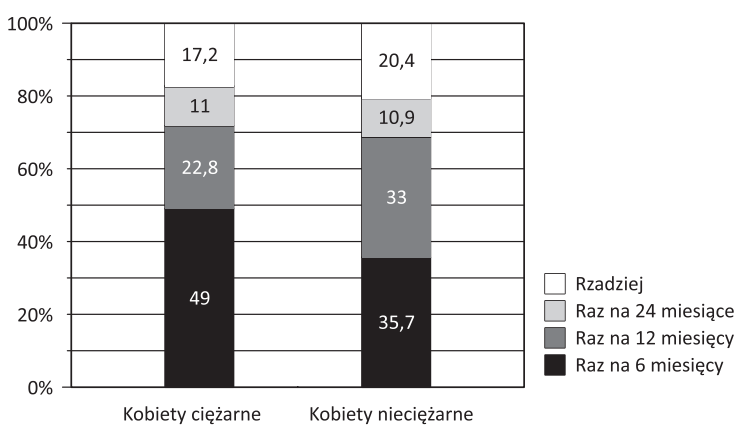

RYCINA 3. Częstotliwość zgłaszania się kobiet na badanie ginekologiczne

Kolejne pytanie wiązało się ze wskazaniem źródeł poczucia bezpieczeństwa i komfortu psychicznego podczas badania ginekologicznego. Na pytanie, z czym wiąże się takie poczucie, $213(53,3 \%)$ kobiet ciężarnych istotnie częściej wskazywało jedynie sytuację, w której pozostaje sam na sam z badającym lekarzem, w przeciwieństwie do respondentek nieciężarnych, które istotnie częściej preferowały obecność tylko jednego lekarza (343 osób - 42,8\%) oraz obecność położnej (310 osób $38,8 \%$ ) w trakcie badania (ryc. 4) - p < 0,05.

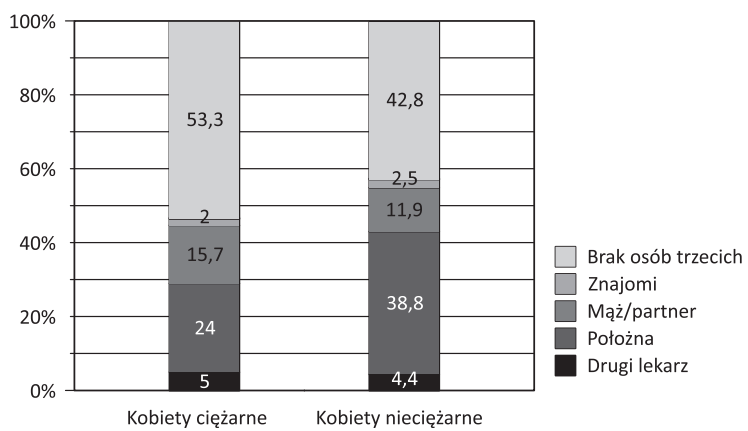

RYCINA 4. Źródła poczucia bezpieczeństwa i komfortu psychicznego podczas badania ginekologicznego

Analizując poczucie intymności pacjentek w trakcie badania ginekologicznego, stwierdzono, że wg 254 (63,5\%) kobiet ciężarnych oraz 502 (62,8\%) nieciężarnych lekarz dbał o zachowanie ich intymności (najczęściej był to parawan zasłaniający fotel ginekologiczny oraz brak osób trzecich). Ponadto większość osób z obu grup stwierdziła, iż badanie ginekologiczne nie sprawiało im bólu (I - 295 osób, 73,7\%; II - 567, 70,1\%). Nie wykazano istotności statystycznych.

Spośród cech, jakie powinien posiadać idealny ginekolog, kobiety zarówno z grupy I, jak i grupy II najchętniej wymieniały: miły (I - 316 osób, 80,2\%; II - 653, 81,8\%), spokojny (I - 230 osób, 58,4\%; II - 479 osób, 60\%) i w dojrzałym wieku (I - 132 osób, 32,6\%; II - 260 osób, 33,5\%).

Analiza preferencji płci lekarza wykazała różnice istotne statystycznie $(p<0,05)$. Respondentki będące w ciąży istotnie częściej wolały być badane przez ginekologa mężczyznę (292 osób-73,0\%) - rycina 5 .

Odpowiadając na pytanie dotyczące niedoborów w wyposażeniu gabinetów ginekologicznych, respondentki z obu grup jednakowo stwierdziły, że najczęściej w gabinetach brakowało

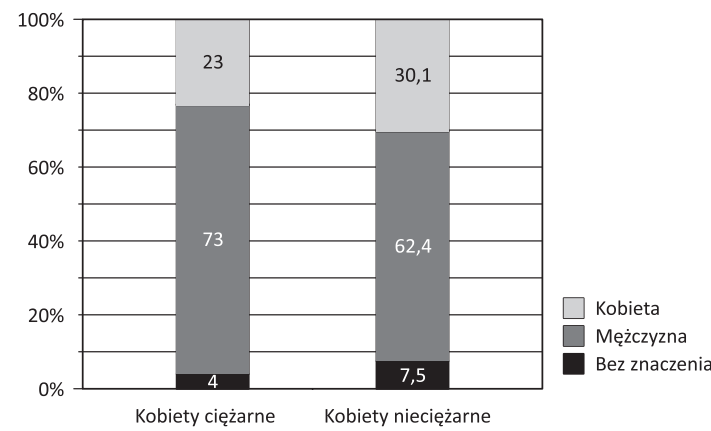

RYCINA 5. Płeć lekarza

im przebieralni/parawanu (I - 30\%; II - 30\%) oraz łazienki/ prysznica/bidetu (I - 15\%; II - 18\%). Natomiast różnica istotna statystycznie pojawiła się jedynie dla braku USG, które istotnie częściej wskazywały respondentki niebędące w ciąży $(p=0,04)$.

\section{DYSKUSJA}

Jednym z ważnych elementów opieki lekarskiej jest dla każdej pacjentki badanie ginekologiczne. Polega ono na oględzinach najbardziej intymnych części ciała, przez co może wywoływać wiele negatywnych uczuć, takich jak: niepokój, wstyd, zażenowanie i zdenerwowanie [1, 2, 3, 4]. W analizowanym materiale wykazano, że respondentki w ciąży zgłaszały istotnie mniejszy dyskomfort w trakcie badania ginekologicznego niż kobiety niebędące w ciąży. Odmienne wyniki przedstawiła Pietras [5], u której większość pacjentek przebywających na oddziale patologii ciąży zgłaszało zakłopotanie i stres podczas badania ginekologicznego $(60,0 \%)$.

Badanie ginekologiczne obejmuje kilka etapów, które powinny następować po sobie wg ustalonego schematu. Całe badanie należy przeprowadzić delikatnie i ostrożnie, uwzględniając anatomię oraz wiek kobiety, ponieważ każdy z etapów może wywoływać ból u pacjentki. Bardzo ważne jest wyjaśnienie celu i istoty badania ginekologicznego oraz uzyskanie zgody na jego przeprowadzenie. Według Synowiec-Piłat [6] badanie piersi, pochwy i podbrzusza powinno być przeprowadzone delikatnie, z zachowaniem komfortu psychicznego i fizycznego pacjentki, przez co zwiększa się zaufanie do lekarza, a także przekonuje kobietę do poddania się kolejnym badaniom w przyszłości. Z badań własnych wynika, że badanie piersi istotnie częściej krępowało respondentki nieciężarne. Podobnie w swoim opracowaniu twierdzi Synowiec-Piłat [6], u której ankietowane nie obawiały się badania piersi przez lekarza i aż 87,0\% uważało, że jest ono niezbędne.

Badanie ginekologiczne jest pierwszym i podstawowym badaniem, które może pomóc we wczesnym wykryciu nowotworów narządu rodnego. Jednak w procesie profilaktyki i diagnostyki tych chorób konieczna jest inicjatywa ze strony pacjentek polegająca na regularnym zgłaszaniu się do lekarza ginekologa w celu wykonania badań kontrolnych. Analiza uzyskanych wyników wykazała, że kobiety ciężarne istotnie częściej zgłaszałyby się na badanie ginekologiczne raz na 6 miesięcy, w przeciwieństwie do ankietowanych niebędących 
w ciąży, które częściej zgłaszałyby się na takie badanie raz na 12 miesięcy. Do większej częstotliwości badań przyczyniły się najprawdopodobniej regularne wizyty kontrolne w czasie ciąży. Potwierdza to w swoich analizach Pietras, u której 90,0\% ankietowanych ciężarnych cyklicznie uczęszczało do lekarza w czasie ciąży [5].

Ważnym aspektem przeprowadzonych badań było ustalenie tego, co zdaniem kobiet daje im poczucie bezpieczeństwa i komfortu psychicznego w trakcie badania. Dla większości pacjentek ciężarnych istotna była obecność wyłącznie jednego lekarza ginekologa w odróżnieniu od ankietowanych niebędących w ciąży, które istotnie częściej preferowały brak osób trzecich oraz dodatkową obecność położnej w trakcie badania.

Analiza materiału dotycząca wyboru płci ginekologa wykazała, że większość respondentek ciężarnych istotnie częściej preferowała mężczyznę jako swojego lekarza. Zbliżone wyniki uzyskano w badaniach przeprowadzonych przez Pietras, w których pacjentki częściej wybierały mężczyznę na lekarza prowadzącego ciążę [5]. Ciekawe wyniki uzyskali także Salih Basama i wsp., którzy wykazali, że płeć ginekologa nie miała znaczenia dla kobiet ciężarnych podczas badania ultrasonograficznego przeprowadzanego sondą dopochwową [7].

Postawa, zachowanie i reakcje lekarza w trakcie wizyty ginekologicznej mają ogromny wpływ na poprawne komunikowanie się z pacjentką oraz na przebieg całego badania. To lekarz tworzy emocjonalną atmosferę zachęcającą lub zniechęcającą do współpracy [8]. Zdaniem badanych kobiet ginekolog powinien być miły, spokojny i w dojrzałym wieku. Podobne wyniki przedstawiła Pietras, u której 48,0\% ankietowanych również preferowało dojrzały lub starszy wiek lekarza ginekologa [5].

\section{WNIOSKI}

1. Badanie ginekologiczne było istotnie bardziej krępujące i stresujące dla kobiet niebędących w ciąży.

2. W opinii kobiet ciężarnych badanie piersi jest najmniej krępującym etapem badania.

3. Kobiety ciężarne istotnie częściej wybierały na swojego lekarza ginekologa mężczyznę.

4. Częstotliwość zgłaszania się na badania ginekologiczne istotnie zależała od stanu brzemiennego kobiety.

5. Oczekiwania badanych kobiet wobec ginekologa skupiały się głównie na zachowaniu przez niego poczucia intymności, bezpieczeństwa oraz na informowaniu o procedurach. Ważne jest także miłe i indywidualne podejście lekarza do pacjentki.

\section{PIŚMIENNICTWO}

1. Makara-Studzińska M, Iwanowicz-Palus G, editors. Psychologia w położnictwie i ginekologii. Warszawa: Wyd. Lekarskie PZWL; 2009.

2. Waszyński E. Zachowanie intymności pacjentki w gabinecie ginekologicznym. Ginek Prakt 2000;8(1):41-2.

3. Chen SL, Chao Yu YM, Tsai DF, Chen MJ. Gynecologists' perception of the patient - physician relationship in pelvic examinations in Taiwan. J Psychosom Obstet Gynaecol 2008;29:290-5.
4. Seehusen DA, Johnson DR, Earwood JS, Sethuraman SN, Cornali J, Gillespie $\mathrm{K}$, at al. Improving women's experience during speculum 13812 examinations at routine gynaecological visit: randomised clinical trial. BMJ 2006;333:171.

5. Pietras J. Preferencje i oczekiwania kobiet. Pielęg Położ 2002;44(4):10-1.

6. Synowiec-Piłat M. Percepcja umiejętności interpersonalnych (komunikacyjnych) lekarzy ginekologów. Ginek Prakt 2003;11(3):19-24.

7. Salih Basama FM, Crosfill F, Price A. The gender of de examiner, the state of the pregnancy and women's perceptions of transvaginal sonography in the first trimester. Eur J Ultrasound 2003;16:237-41.

8. Barański J, Waszyński E, Steciwko A, editors. Komunikowanie się lekarza z pacjentem. Wrocław: Wyd. Astrum; 2000.

\section{ANKIETA}

\section{Wiek}
$\square \quad 20$ lat i mniej
20-40 lat
ㄴ 41-60 lat
$\square 61$ lat i więcej

\section{Miejsce zamieszkania}

$\square$ miasto $\square$ wieś

1. Czy badanie ginekologiczne jest dla Pani krępujące?
a. Tak
b. Nie

2. Który moment wizyty u lekarza ginekologa najbardziej Panią krępuje?
a. Wejście do gabinetu
b. Wywiad
c. Przygotowanie do badania (rozebranie się)
d. Położenie na fotel
e. Badanie ginekologiczne
f. Rozmowa z lekarzem po badaniu

3. Który etap badania ginekologicznego najbardziej Panią krępuje?
a. Badanie przez pochwę we wziernikach
b. Badanie przez pochwę ręczne
c. Badanie przez odbytnicę
d. Badanie piersi

4. Czy woli być Pani badana przez mężczyznę czy kobietę?
a. Kobietę
b. Mężczyznę
c. Bez znaczenia

5. Uważa Pani, że badanie ginekologiczne jest potrzebne?
a. Tak
b. Nie

6. Jak często bada się Pani ginekologicznie (poza ciążą)?
a. Raz na 6 miesięcy
b. Raz na 12 miesięcy
c. Raz na 24 miesiące
d. Rzadziej 
7. Czy podczas pierwszego w życiu badania ginekologicznego lekarz tłumaczył Pani, na czym ono polega?
a. Tak
b. Nie
c. Nie pamiętam

8. Czy uważa Pani, że lekarz powinien tłumaczyć kobietom, na czym polega badanie ginekologiczne i informować o każdej kolejnej czynności?

a. Tak

b. Nie, nie ma takiej potrzeby

9. Czy podczas badania wewnętrznego lekarz dba o Pani intymność?
a. Tak. W jaki sposób?
b. Nie

10. Czy badanie ginekologiczne sprawia Pani ból?
a. Tak
b. Nie

11. Jaki Pani zdaniem powinien być lekarz ginekolog? Proszę zaznaczyć trzy cechy dla Pani najważniejsze.
a. Miły
b. Uśmiechnięty
c. Rozmowny
d. Małomówny
e. Spokojny
f. Przystojny
g. Młody
h. Dojrzały

12. Co Pani zdaniem daje poczucie bezpieczeństwa i komfortu psychicznego podczas badania ginekologicznego?

a. Obecność drugiego lekarza

b. Obecność wykwalifikowanej położnej

c. Obecność męża/partnera

d. Obecność znajomych lub koleżanek

e. Brak innych osób

13. Czego brakuje Pani w gabinetach ginekologicznych?

14. Czy chciałaby Pani, aby w gabinetach ginekologicznych była możliwość skorzystania z bidetu lub prysznica?

a. Tak, przed przystąpieniem do badania

b. Tak, po badaniu

c. Nie, korzystam z prysznica $\mathrm{w}$ domu 